\title{
STUDI TERHADAP MAHASISWA USM UNTUK MELIHAT DAMPAK NEGATIF MEROKOK DENGAN MENGGUNAKAN SPSS 12
}

\begin{abstract}
ABSTRAK
Sering kali, apabila pada situasi menuntut kita untuk mengambil tindakan keputusan, kita harus memutuskan untuk memilih satu dari dua atau lebih alternatif tindakan yang dapat diambil. Pilihan akan sederhana jika setiap tindakan hanya memiliki satu konsekuensi dan konsekuensi tersebut diketahui secara pasti, sehingga pengambilan keputusan memilih tindakan yang memiliki konsekuensi paling sesuai dengan keinginan kita. Dengan kata lain, pengambilan keputusan cenderung pada kemungkinankemungkinan yang memiliki konsekuensi akan terjadi.

Adalah suatu aturan tertentu untuk mengambil keputusan dengan menggambarkan proses yang digunakan untuk memilih suatu tindakan sebagai cara pememcahan masalah yang disebut dengan sistem pendukung pengambilan keputusan atau decision support system. Sedangkan statistik merupakan suatu teknik pengumpulan hasil analisa yang didapat dari observasi dan lain dari sampel yang ada. Jadi pengambilan keputusan jika dilihat dari sudut pandang teori pengambilan keputusan secara statistik, adalah suatu situasi pengambilan keputusan pada kondisi tidak pasti, yang dinyatakan dalam bentuk tabel, diagram, polygon, histogram an lain sebagainya yang mendeskripsikan situasi tersebut. Dimana mereka ( diagram, polygon, histogram...red ) mengidentifikasikan keuntungan maksimal dan kerugian minimal yang didapat untuk memungkinkan diwujudkan dalam bentuk tindakan, berikut berikut alternatif yang ada. Selain itu hasil dari analisa juga mengidentifikasikan probabilitas untuk setiap kejadian yang saling meniadakan ( utually exclusive ).
\end{abstract}

Kata kunci : pengambilan keputusan, statistik, analisa 


\title{
STUDI TO USM'S COLLEGE STUDENT TO SEE NEGATIVE IMPACT SMOKES BY USE OF SPSS 12
}

\begin{abstract}
EDLY
Oft, if on situation charges to take action decision, we shall decide to choose one of two or more takeable action alternatives. Option will simple if each action just have one consequence and that consequence is acknowledged ala must, so decision making chooses action that have utmost consequence corresponds to to make mouth water we. In other words, tending decision making on possible that have consequence will happen.

Are an order givening to take a decision with figure process that is utilized to choose an action as pememcahan's trick the so called problem with decisions making supporting system or decision support system . Meanwhile statistic constitute a collecting tech usufructs to analyse that is gotten from observation and any other of aught sample. So decision making if is seen from decision making theory viewpoint statistically, are a situated decision making on condition of incertain, one that is declared for deep tabular, diagram, polygon, an's histogram any other as it who describe that situation. Where are they( diagram, polygon, histogram ... red) mengidentifikasikan is maximal gain and disadvantaged minimal one is gotten to enable is rendered deep shaped action, aughts alternative followings. Besides result of analysis also mengidentifikasikan probability for each instance which mutually negates( utually exclusive ).
\end{abstract}

Key word: decision making, statistic, analysis 